\title{
Paleomagnetism of Meta-Igneous Rocks from the Labrador Trough
}

\author{
Maurice K.-SEGUIN \\ Département de Géologie, Université Laval, \\ Québec, Canada
}

(Received February 4, 1976; Revised May 6, 1976)

\begin{abstract}
Forty-five oriented samples were collected from 38 different sites on northwest striking flows and gabbro sills of Lower Proterozoic (Aphebian) age in the central portion of the Labrador Trough (longitude: $67^{\circ} \mathrm{W}$, latitude: $56^{\circ} \mathrm{N}$ ). These were demagnetized in an alternating magnetic field. The decrease in NRM intensity during AF demagnetization is rapid in the range: $0.5-100 \mathrm{Oe}$ and relatively insignificant between 150 and 1,100 Oe. About $45 \%$ of the specimens were found to be unstable and $30 \%$ of the metalava and metagabbro specimens are characterized by the presence of a second magnetization superimposed on the first one.

The fold test was applied in all cases. After unfolding the intrusive and extrusive rocks, the main paleomagnetic pole position of the Murdoch metavolcanics and intrusives, the gabbros intrusive into the Thompson Lake formation and the gabbros intrusive into the Menihek formation combined with the metabasalts interstratified with this formation are respectively $159^{\circ} \mathrm{E}: 30^{\circ} \mathrm{N}$, $184^{\circ} \mathrm{E}: 02^{\circ} \mathrm{N}$, and $204^{\circ} \mathrm{E}: 03^{\circ} \mathrm{N}$. The pole position of all the different formations combined is $172^{\circ} \mathrm{W}: 08^{\circ} \mathrm{N}$, it is situated in central North Pacific ocean. This indicates that the Labrador Trough was near the equator at the time of extrusion and intrusion.
\end{abstract}

\section{Introduction}

This study is centered on the paleomagnetism of the basic intrusive and extrusive rocks of the central eastern portion of the Labrador geosyncline. Since paleomagnetism is becoming of greater importance in determining the time sequence of Precambrian rocks and in studying the nature of Precambrian orogenies, many additional paleomagnetic studies ought to be conducted in order to determine the variations of the Precambrian geomagnetic field. This study is a small contribution to this general requirement but it is of interest since no definitive trend of the apparent polar wandering path has yet been firmly established for the 1,200-2,000 m.y. span (MCGLYNN et al., 1974; MCGLYNN and IRVING, 1975). Such uncertainties call for additional paleomagnetic results from 
rocks that were magnetized in that period, and in this respect the Labrador Trough is an untapped source of new paleomagnetic data (SEguin, 1972a, b, 1974).

\section{Geology}

The Murdoch greenschists belonging to the Doublet group of the central Labrador eastern eugeosynclinal basin are separated from the sedimentary Knob Lake group of the western miogeosynclinal basin by a north-westerly trending regional fault (thrust). The chlorite-biotite-quartz and chlorite-albite-actinolite schists which compose the Murdoch formation occur on the east side of this regional thrust fault (structural discordance). The Murdoch formation originally consisted of basaltic pyroclastic rocks, massive basalt flows, lapilli and ash tuffs as well as massive intrusive rocks (DonAldson, 1959, 1966; Dimroth, 1965a, 1967, 1969, 1970, 1971). The Murdoch formation is overlain by the Thompson Lake slate of the Doublet group. Gabbro sheets which may have an intrusive or an extrusive origin are present both in the Thompson Lake slate and in the Menihek slate of the Knob Lake group underlying unconformably the Murdoch formation. Normal and glomeroporphyritic gabbros occur in the Menihek formation (Frarey, 1952, 1961, 1967; BARAGAR, 1958, 1960, 1963, 1967). Glomeroporphyritic gabbros (leopard rock) are restricted to the Doublet group; they form an intrusive-extrusive complex in the Murdoch formation. The same metagabbros intrude the Thompson Lake slate (BARAGAR, 1958, 1960; FraReY, 1952, 1967).

The different Lower Proterozoic rock types described display a $\mathrm{N} 35^{\circ}-45^{\circ} \mathrm{W}$ regional trend with variable local strikes; the dips of the formations are generally vertical to sub-vertical. These formations were tightly folded and in many instances refolded so that a certain number of layers are now slightly overturned; the tops were mainly recognized by the pillows in the lavas. These rocks suffered a synkinematic and post-kinematic metamorphism in the pumpellyite-prehnite greenschist facies. Folding and metamorphism appear to be simultaneous (Dimroth et al., 1970).

\section{Age}

The relative age of the different rock types investigated in this study can be established with some precision. FrYER (1972) gave a radiogenic K-Ar age of $1,855 \mp 74 \mathrm{~m} . \mathrm{y}$. for the Menihek slate formation intruded by normal and glomeroporphyritic gabbros (PM series) and into which basalt flows (PM 2-2) are present. In the Patu Lake area, some $65 \mathrm{~km}$ north of the area investigated

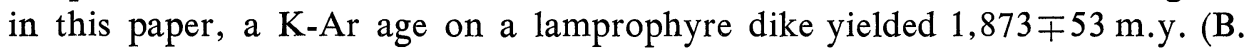


Dressler, personal communication). The metabasalt flows interbedded with the Menihek slate and the gabbro intrusives into this formation thus have an age located between 1,780 and 1,930 m.y. The Murdoch formation and the basic intrusives int $\odot$ the Thompson Lake metasediments may have a slightly younger age.

\section{Sampling Procedure}

Some 45 oriented samples were collected by the hand sample method on 38 different sites: the number of samples per site varied between 1 and 3. Two specimens and occasionally 3 were cut from each hand sample. In this regional survey, efforts were made to select fresh samples from sites where there was an excellent exposure and where the structural geology was best understood. Except for iron formation, the formations are not anomalously magnetic and a magnetic compass could be used for the orientation of the rock samples.

\section{Measurements}

Magnetic susceptibility measurements were made with a standardized resistance bridge manufactured by Cenco Instruments Corporation having a precision of $5 \times 10^{-7} \mathrm{cgs}$ emu (SEGUIN, 1972b). The direction and intensity of remanent magnetization was measured by means of a custom built spinner magnetometer (sensitivity is $10^{-7} \mathrm{cgs}$ emu). Alternating field demagnetization was carried out to remove unwanted secondary components using the demagnetizer built at the Universite of Laval having a maximum peak-to-peak intensity of 2,000 Oe.

\section{Magnetic Susceptibilities and Koenigsberger Ratios}

Histograms of the volume ferromagnetic susceptibilities and Koenigsberger ratios were constructed. Figure 1 shows a histogram of the magnetic susceptibilities of the Murdoch formation and the different gabbros. Both histograms are bimodal. To some extent, this reflects the original mineralogy as correlated with the geochemistry of the samples. But this is far from a general case and consequently the superimposed metamorphism is largely responsible for this situation. The modal values for the gabbros are $7.2 \times 10^{-5}$ and $4.6 \times 10^{-3} \mathrm{cgs} \mathrm{emu} / \mathrm{cc}$. The mean susceptibility value is $7 \times 10^{-5} \mathrm{cgs} \mathrm{emu} / \mathrm{cc}$ for the metasediments $(N=$ 22) and $6 \times 10^{-3} \mathrm{cgs} \mathrm{emu} / \mathrm{cc}$ for the serpentinites $(N=13)$. Figure 2 shows a histogram of the Koenigsberger ratio $(R)$ for the Murdoch formation and the different gabbros. Both histograms indicate a large scatter for the values of $R$. The one of the Murdoch formation shows a more or less normal distribution with a peak value at 0.4 whereas the one of the different gabbros is bimodal 

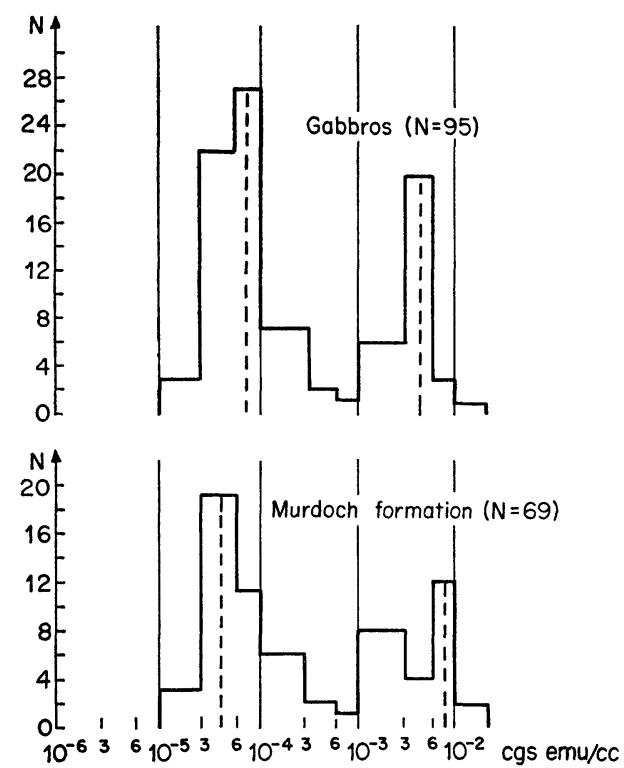

Fig. 1. Histogram of the magnetic susceptibilities for the different geological formations investigated.
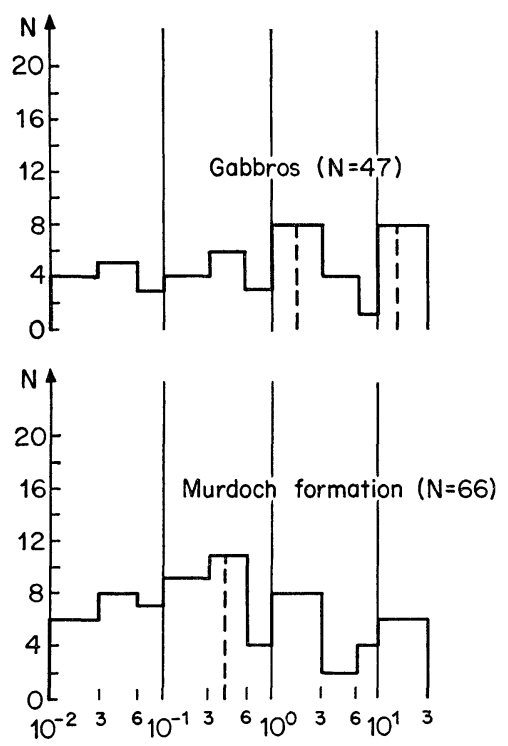

Fig. 2. Histogram of the Koenigsberger ratio for the same geological formations.

with modal values at 1.7 and 13 . Consequently, the NRM intensity is much larger in the gabbros than in the Murdoch greenschists.

7. Alternating Field Demagnetization

At least one specimen from each of the 38 sites was demagnetized in steps 


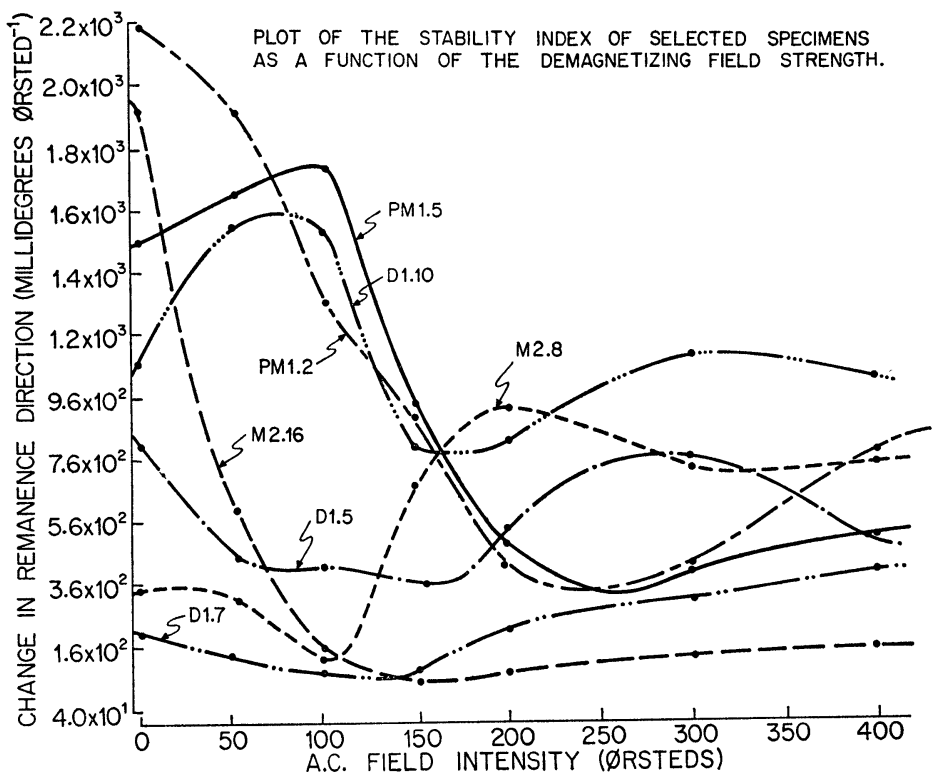

Fig. 3. Plot of the stability index of some specimens of the geological formations.

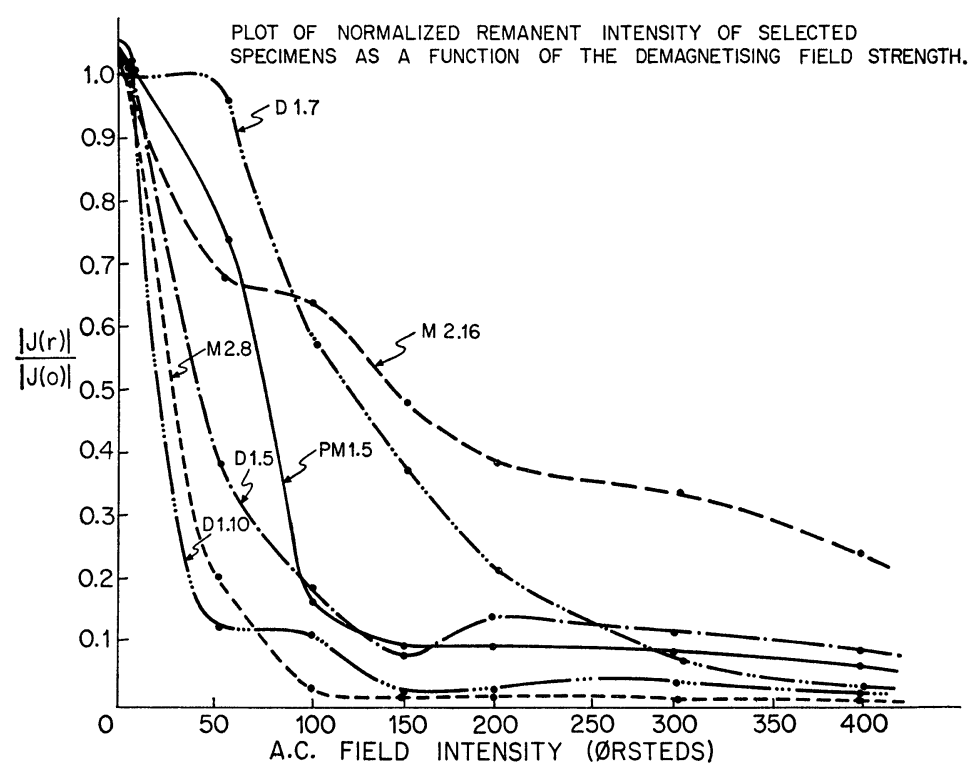

Fig. 4. Plot of normalized remanent intensity of typical specimens as a function of the demagnetizing field strength. 


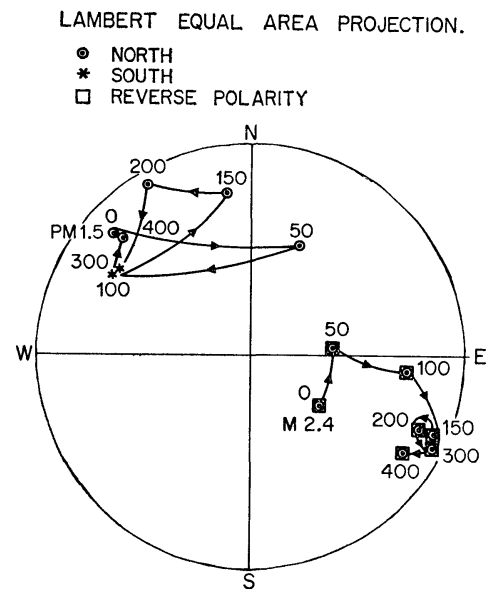

Fig. 5. Variation of the magnetization directions of a few pilot specimens of the geological formations investigated as a function of the demagnetizing AF strength. North= North pole; South $=$ South pole.

of $50 \mathrm{Oe}$ from 50 to $700 \mathrm{Oe}$ and occasionally up to $1,100 \mathrm{Oe}$ in the absence of an ambient field. Guided by the stepwise changes in remanence and intensity of the pilot specimen(s) of the site, an objective "end point" stability method was used in which the remaining specimens from the site were AF demagnetized and their residual remanence measured (Symons and Stupavsky, 1973). Pilot tests show that the AF intensity at which the primary thermoremanent component is most thoroughly isolated is about 100 to 300 Oe (Fig. 3), but there are some exceptions. Most specimens of Murdoch formation (M series) and gabbros intrusive into the Thompson Lake formation (D series) are magnetically stable in the 100-200 Oe range. The large majority of the gabbros intrusive into the Menihek formation (PM series) are magnetically stable in the 200-300 Oe range. Normalized curves for some typical test specimens from a few sites are shown on Fig. 4. Median destructive fields (m.d.f.) are usually between 80 and 200 Oe. The magnetization directions of pilot specimens from 2 sites are presented in Fig. 5. All the other specimens were AF demagnetized at successive intensities of 100 to $300 \mathrm{Oe}$ in steps of $50 \mathrm{Oe}$.

\section{Statistics and Grouping}

The vector sum of the unit vectors $\boldsymbol{R}$ representing the magnetization of the specimens from a given hand sample was calculated and taken as the mean direction of magnetization for that hand sample (FISHER, 1953). If the magnetization vectors diverged by an angle (angular standard deviation; IRVING, 1964) exceeding $33^{\circ}$ after AF demagnetization, they were termed inhomogeneous and were not included in any further analysis; $58 \%$ of the hand samples are homogeneous after demagnetization. 


\section{Results of Paleomagnetic Measurements}

The NRM directions of the different geological formations investigated are widely scattered (both within and between hand sample scatter). Before AF demagnetization, the mean direction of the NRM orientations of all the geological formations is $274^{\circ},-10^{\circ}$. After AF demagnetization, between 100 and $300 \mathrm{Oe}$ (peak-to-peak), the dispersion within and between sites generally decreased and the site mean directions became grouped about an east-west axis with low inclination. The stable component after AF cleaning is much smaller than the initial NRM intensity; the average ratio of the mean site intensities before and after cleaning at $250 \mathrm{Oe}$ is 0.13 . The mean direction of the AF demagnetized $\mathrm{NRM}$ orientations is $284^{\circ},-04^{\circ}$ with a corresponding paleopole position of $172^{\circ} \mathrm{W}: 07^{\circ} \mathrm{N}$. The dispersion of the pole is still relatively large after AF cleaning. On demagnetization, specimen magnetization directions were found to move to westerly azimuths and sites which originally gave directions with low negative inclinations moved most commonly in such a way that stable endpoints in direction yielded low positive inclinations. The significance and stability of the different formations investigated in this study are demonstrated by the departure of the site NRM directions from the recent Earth's field direction $\left(331^{\circ}, 79^{\circ} \mathrm{N}\right)$ and the evidence for reversal(s).

\section{Curie Temperatures}

Thermomagnetic curves were obtained on $10 \mathrm{mg}$ of powdered rock samples using a recording electromagnetic microbalance. Most of the curves obtained are relatively simple and indicate the presence of a single magnetic mineral having Curie temperature in the $560^{\circ}-590^{\circ} \mathrm{C}$ temperature range; these data suggest that the magnetic mineral is almost pure magnetite. In a few samples, low temperature Curie points suggest the presence of small quantities of hemo-ilmenite.

\section{Time (Age) and Origin of Magnetization}

The meaning of radiogenic age determinations, particularly of Precambrian rocks, is difficult to interpret and their relationship to paleomagnetic studies have been discussed by a number of authors (FAHRIG and JonEs, 1969; Irving et $a l ., 1972$ ). Fold tests conducted on both natural and demagnetized rock types generally lead to smaller angle of dispersion after correction for tilt (Tables 1 and 2). This tilt correction was applied using individual and local structural rotations taken from data collected at each specific sampling site. To my knowledge, an improvement of large $\alpha_{0.95}$ values after unfolding suggests that a large fraction of the NRM component is of pre-tectonic and pre-metamorphic origin 
Table 1. Statistical study of the paleopoles of the different rock types before AF demagnetization.

\begin{tabular}{|c|c|c|c|c|c|c|c|c|}
\hline \multirow{2}{*}{$\begin{array}{l}\text { Group } \\
\text { No. }\end{array}$} & \multirow{2}{*}{$\begin{array}{l}\text { Site } \\
\text { No. }\end{array}$} & \multicolumn{4}{|c|}{ Without fold test } & \multicolumn{3}{|c|}{ With fold test } \\
\hline & & $N$ & $\begin{array}{c}D_{2} \\
\text { (degrees) }\end{array}$ & $\begin{array}{c}I_{2} \\
\text { (degrees) }\end{array}$ & $\begin{array}{c}\alpha_{0.95} \\
\left({ }^{\circ}\right)\end{array}$ & $\begin{array}{c}D_{1} \\
\text { (degrees) }\end{array}$ & $\begin{array}{c}I_{1} \\
\text { (degrees) }\end{array}$ & $\begin{array}{c}\alpha_{0.95} \\
\left({ }^{\circ}\right)\end{array}$ \\
\hline \multicolumn{9}{|c|}{ Murdoch formation (Greenshists) } \\
\hline \multirow[t]{11}{*}{$\mathbf{M}$} & 21 & 3 & 149 & -19 & 06 & 147 & -44 & 42 \\
\hline & 22 & 5 & 212 & 04 & 19 & 283 & 32 & 13 \\
\hline & 23 & 2 & 059 & -62 & 49 & 185 & -21 & 25 \\
\hline & 24 & 4 & 278 & -41 & 21 & 287 & 04 & 14 \\
\hline & 25 & 8 & 354 & -45 & 16 & 323 & -22 & 08 \\
\hline & 26 & 2 & 221 & -11 & 51 & 223 & -52 & 26 \\
\hline & 27 & 3 & 080 & -06 & 14 & 245 & -65 & 16 \\
\hline & 28 & 2 & 301 & 24 & 71 & 319 & 39 & 65 \\
\hline & 29 & 2 & 214 & 49 & 36 & 237 & -33 & 36 \\
\hline & 211 & 5 & 254 & -43 & 38 & 339 & -22 & 39 \\
\hline & 216 & 3 & 163 & -49 & 07 & 300 & -63 & 07 \\
\hline \multirow{2}{*}{\multicolumn{2}{|c|}{$\begin{array}{l}\text { Total and mean: } \\
\text { Pole position: }\end{array}$}} & $11(39)$ & 221 & -56 & 18 & 292 & -27 & 31 \\
\hline & & & $220^{\circ} \mathrm{E}:$ & $56^{\circ} \mathrm{S}$ & & $177^{\circ} \mathrm{E}:$ & $00^{\circ}$ & \\
\hline \multicolumn{9}{|c|}{ Gabbros intruded into Thompson Lake formation } \\
\hline \multirow[t]{10}{*}{$\mathbf{D}$} & 11 & 2 & 310 & -37 & 15 & 303 & 13 & 17 \\
\hline & 12 & 4 & 296 & -17 & 54 & 240 & -42 & 19 \\
\hline & 14 & 2 & 220 & -20 & 16 & 197 & -30 & 17 \\
\hline & 15 & 2 & 244 & 70 & 40 & 179 & -13 & 68 \\
\hline & 16 & 2 & 213 & 35 & 65 & 284 & 41 & 65 \\
\hline & 17 & 4 & 002 & -03 & 17 & 332 & 49 & 14 \\
\hline & 18 & 3 & 240 & 22 & 63 & 234 & 34 & 66 \\
\hline & 113 & 5 & 313 & 04 & 22 & 295 & 43 & 22 \\
\hline & 114 & 3 & 248 & 85 & 18 & 236 & -01 & 18 \\
\hline & 115 & 3 & 309 & -31 & 12 & 298 & 18 & 11 \\
\hline \multirow{2}{*}{\multicolumn{2}{|c|}{$\begin{array}{l}\text { Total and mean: } \\
\text { Pole position: }\end{array}$}} & $10(30)$ & 299 & 10 & 25 & 266 & 18 & 33 \\
\hline & & & $182^{\circ} \mathrm{E}:$ & $20^{\circ} \mathrm{S}$ & & $212^{\circ} \mathrm{E}:$ & $06^{\circ} \mathrm{N}$ & \\
\hline \multicolumn{9}{|c|}{ Gabbros intrusive into Menihek formation } \\
\hline \multirow[t]{9}{*}{ PM } & 11 & 2 & 270 & 52 & 62 & 276 & -19 & 54 \\
\hline & 12 & 3 & 318 & 38 & 38 & 300 & -06 & 33 \\
\hline & 14 & 4 & 187 & -03 & 49 & 231 & 35 & 51 \\
\hline & 15 & 2 & 324 & 32 & 52 & 316 & -10 & 56 \\
\hline & 16 & 6 & 259 & 25 & 18 & 263 & -34 & 18 \\
\hline & 17 & 2 & 282 & -24 & 66 & 270 & -57 & 64 \\
\hline & 18 & 3 & 241 & -42 & 63 & 232 & 01 & 66 \\
\hline & 19 & 2 & 186 & -39 & 29 & 205 & 21 & 24 \\
\hline & 21 & 3 & 254 & -17 & 21 & 279 & -54 & 21 \\
\hline \multirow{2}{*}{\multicolumn{2}{|c|}{$\begin{array}{l}\text { Total and mean: } \\
\text { Pole position: }\end{array}$}} & $9(27)$ & 257 & 06 & 25 & 264 & -20 & 34 \\
\hline & & & $217^{\circ} \mathrm{E}:$ & $05^{\circ} \mathrm{S}$ & & $202^{\circ} \mathrm{E}:$ & $11^{\circ} \mathrm{S}$ & \\
\hline
\end{tabular}


Table 1. (continued)

\begin{tabular}{|c|c|c|c|c|c|c|c|c|}
\hline \multirow{2}{*}{$\begin{array}{c}\text { Group } \\
\text { No. }\end{array}$} & \multirow{2}{*}{$\begin{array}{l}\text { Site } \\
\text { No. }\end{array}$} & \multicolumn{4}{|c|}{ Without fold test } & \multicolumn{3}{|c|}{ With fold test } \\
\hline & & $N$ & $\begin{array}{c}D_{2} \\
\text { (degrees) }\end{array}$ & $\begin{array}{c}I_{2} \\
\text { (degrees) }\end{array}$ & $\begin{array}{c}\alpha_{0.95} \\
\left({ }^{\circ}\right)\end{array}$ & $\begin{array}{c}D_{1} \\
\text { (degrees) }\end{array}$ & $\begin{array}{c}I_{1} \\
\text { (degrees) }\end{array}$ & $\begin{array}{c}\alpha_{0.95} \\
\left(^{\circ}\right)\end{array}$ \\
\hline & & & & & & & \multicolumn{2}{|c|}{ Basalts } \\
\hline $4 \mathrm{PM}$ & 22 & 6 & 223 & 20 & 17 & 269 & 25 & 25 \\
\hline $\mathbf{P M}$ & 24 & 2 & 228 & 04 & 49 & 221 & -29 & 44 \\
\hline \multicolumn{2}{|c|}{$\begin{array}{l}\text { Total and mean: } \\
\text { Pole position: }\end{array}$} & $2(8)$ & $\begin{array}{l}224 \\
248^{\circ} \mathrm{E}:\end{array}$ & $\begin{array}{l}17 \\
16^{\circ} \mathrm{S}\end{array}$ & 24 & $\begin{array}{l}259 \\
216^{\circ} \mathrm{E}:\end{array}$ & $\begin{array}{l}17 \\
01^{\circ} \mathrm{N}\end{array}$ & 23 \\
\hline & & & & & & & \multicolumn{2}{|c|}{ Serpentinites } \\
\hline $5 \mathrm{D}$ & 19 & 2 & 289 & -24 & 02 & 304 & -03 & 44 \\
\hline D & 112 & 2 & 154 & -55 & 62 & 340 & -60 & 56 \\
\hline \multicolumn{2}{|c|}{$\begin{array}{l}\text { Total and mean: } \\
\text { Pole position: }\end{array}$} & $2(4)$ & $\begin{array}{l}250 \\
192^{\circ} \mathrm{E}:\end{array}$ & $\begin{array}{l}-40 \\
34^{\circ} \mathrm{S}\end{array}$ & 37 & $\begin{array}{l}316 \\
156^{\circ} \mathrm{E}:\end{array}$ & $\begin{array}{l}-33 \\
07^{\circ} \mathrm{N}\end{array}$ & 47 \\
\hline & & & & & & & \multicolumn{2}{|c|}{ Metasediments } \\
\hline $6 \mathrm{M}$ & 210 & 2 & 029 & -63 & 68 & 261 & -41 & 63 \\
\hline $\mathbf{M}$ & 223 & 3 & 220 & -22 & 17 & 227 & 15 & 17 \\
\hline $\mathrm{D}$ & 110 & 3 & 258 & -30 & 60 & 319 & -22 & 51 \\
\hline \multicolumn{2}{|c|}{$\begin{array}{l}\text { Total and mean: } \\
\text { Pole position: }\end{array}$} & $3(8)$ & $\begin{array}{l}240 \\
213^{\circ} \mathrm{E}:\end{array}$ & $\begin{array}{r}-42 \\
37^{\circ} \mathrm{S}\end{array}$ & 34 & $\begin{array}{l}261 \\
207^{\circ} \mathrm{E}:\end{array}$ & $\begin{aligned}-12 \\
10^{\circ} \mathrm{S}\end{aligned}$ & 36 \\
\hline \multicolumn{2}{|c|}{$\begin{array}{l}\text { Grand averages: } \\
\text { Pole position: }\end{array}$} & $37(116)$ & $\begin{array}{l}258 \\
209^{\circ} \mathrm{E}:\end{array}$ & $\begin{array}{l}-15 \\
13^{\circ} \mathrm{S}\end{array}$ & 29 & $\begin{array}{l}274 \\
197^{\circ} \mathrm{E}:\end{array}$ & $\begin{aligned}-10 \\
02^{\circ} \mathrm{S}\end{aligned}$ & 27 \\
\hline
\end{tabular}

Table 2. Statistical study of the paleopoles of the different rock types after AF demagnetization.

\begin{tabular}{|c|c|c|c|c|c|c|c|c|}
\hline \multirow{2}{*}{$\begin{array}{l}\text { Group } \\
\text { No. }\end{array}$} & \multirow{2}{*}{$\begin{array}{l}\text { Site } \\
\text { No. }\end{array}$} & \multicolumn{4}{|c|}{ Formations not tilted back } & \multicolumn{3}{|c|}{ Formations tilted } \\
\hline & & $N$ & $\begin{array}{c}D_{2} \\
\text { (degrees) }\end{array}$ & $\begin{array}{c}I_{2} \\
\text { (degrees) }\end{array}$ & $\begin{array}{c}\alpha_{0.95} \\
\left({ }^{\circ}\right)\end{array}$ & $\begin{array}{c}D_{1} \\
\text { (degrees) }\end{array}$ & $\begin{array}{c}I_{1} \\
\text { (degrees) }\end{array}$ & $\begin{array}{c}\alpha_{0.95} \\
\left({ }^{\circ}\right)\end{array}$ \\
\hline \multicolumn{9}{|c|}{ Murdoch formation (Greenshists) } \\
\hline \multirow[t]{11}{*}{$\mathbf{M}$} & 21 & 3 & \multicolumn{2}{|c|}{ UNS. } & \multicolumn{4}{|c|}{ UNS. ${ }^{11}$} \\
\hline & 22 & 4 & 221 & 40 & 20 & 304 & 02 & 21 \\
\hline & 23 & 2 & \multicolumn{2}{|c|}{ UNS. } & \multicolumn{4}{|c|}{ UNS. } \\
\hline & 24 & 3 & 341 & -14 & 32 & 344 & 29 & 31 \\
\hline & 25 & 6 & 315 & -40 & 13 & 303 & 03 & 14 \\
\hline & 26 & 2 & \multicolumn{2}{|c|}{ UNS. } & \multicolumn{4}{|c|}{ UNS. } \\
\hline & 27 & 3 & 358 & -69 & 09 & 278 & 12 & 10 \\
\hline & 28 & 2 & \multicolumn{2}{|c|}{ UNS. } & \multicolumn{4}{|c|}{ UNS. } \\
\hline & 29 & 3 & 026 & -35 & 17 & 042 & 25 & 18 \\
\hline & 211 & 4 & 261 & -37 & 32 & 331 & -09 & 27 \\
\hline & $216^{21}(?)$ & 3 & 003 & 23 & 31 & 057 & 35 & 32 \\
\hline \multicolumn{2}{|c|}{$\begin{array}{l}\text { Total and mean: } \\
\text { Pole position: }\end{array}$} & $7(26)$ & 287 & -27 & 24 & $\begin{array}{l}312 \\
159^{\circ} \mathrm{E}:\end{array}$ & $\begin{array}{l}13 \\
31^{\circ} \mathrm{N}\end{array}$ & 22 \\
\hline
\end{tabular}


Table 2. (continued)

\begin{tabular}{|c|c|c|c|c|c|c|c|c|}
\hline \multirow{2}{*}{$\begin{array}{l}\text { Group } \\
\text { No. }\end{array}$} & \multirow{2}{*}{$\begin{array}{l}\text { Site } \\
\text { No. }\end{array}$} & \multicolumn{4}{|c|}{ Formations not tilted back } & \multicolumn{3}{|c|}{ Formations tilted } \\
\hline & & $N$ & $\begin{array}{c}D_{2} \\
\text { (degrees) }\end{array}$ & $\begin{array}{c}\boldsymbol{I}_{2} \\
\text { (degrees) }\end{array}$ & $\begin{array}{c}\alpha_{0.95} \\
\left({ }^{\circ}\right)\end{array}$ & $\begin{array}{c}D_{1} \\
\text { (degrees) }\end{array}$ & $\begin{array}{c}I_{1} \\
\text { (degrees) }\end{array}$ & $\begin{array}{c}\alpha_{0.95} \\
\left({ }^{\circ}\right)\end{array}$ \\
\hline \multicolumn{9}{|c|}{ Gabbros intruded into Thompson Lake formation } \\
\hline \multirow[t]{10}{*}{ D } & 11 & 3 & 304 & -81 & 32 & 279 & -24 & 31 \\
\hline & 12 & 3 & 289 & 34 & 28 & 285 & -29 & 18 \\
\hline & 14 & 3 & 298 & 25 & 31 & 298 & -22 & 30 \\
\hline & 15 & 3 & 250 & -71 & 30 & 311 & 00 & 29 \\
\hline & 16 & 2 & \multicolumn{3}{|c|}{ UNS. } & \multicolumn{2}{|c|}{ UNS. } & \\
\hline & 17 & 3 & & & & UN & & \\
\hline & 18 & 3 & \multicolumn{2}{|c|}{$\begin{array}{l}\text { UNS. } \\
\text { UNS. }\end{array}$} & & \multicolumn{2}{|c|}{ UNS. } & \\
\hline & 113 & 4 & 339 & -69 & 27 & 346 & -16 & 26 \\
\hline & $114^{2}$ & 3 & 236 & -59 & 11 & 055 & 31 & 11 \\
\hline & $115^{2)}$ & 2 & 048 & 84 & 24 & 059 & 06 & 28 \\
\hline \multicolumn{2}{|c|}{$\begin{array}{l}\text { Total and mean: } \\
\text { Pole position: }\end{array}$} & $7(21)$ & 278 & -44 & 28 & $\begin{array}{l}286 \\
184^{\circ} \mathrm{E}:\end{array}$ & $\begin{array}{l}-17 \\
01^{\circ} \mathrm{N}\end{array}$ & 25 \\
\hline
\end{tabular}

\begin{tabular}{|c|c|c|c|c|c|c|c|c|}
\hline \multicolumn{9}{|c|}{ Gabbros intrusive into Menihek formation } \\
\hline \multirow[t]{9}{*}{ PM } & 11 & 2 & \multirow{2}{*}{\multicolumn{2}{|c|}{$\begin{array}{l}\text { UNS. } \\
\text { UNS. }\end{array}$}} & \multirow{2}{*}{\multicolumn{4}{|c|}{$\begin{array}{l}\text { UNS. } \\
\text { UNS. }\end{array}$}} \\
\hline & 12 & 3 & & & & & & \\
\hline & 14 & 2 & 301 & 70 & 28 & 308 & -34 & 27 \\
\hline & 15 & 2 & 344 & 54 & 25 & 311 & 15 & 22 \\
\hline & 16 & 4 & 001 & 61 & 18 & 267 & 34 & 17 \\
\hline & 17 & 3 & 271 & -46 & 13 & 225 & -32 & 12 \\
\hline & 18 & 2 & 242 & -25 & 23 & 240 & 16 & 28 \\
\hline & 19 & 3 & 077 & -67 & 20 & 252 & -15 & 29 \\
\hline & 21 & 3 & \multicolumn{2}{|c|}{ UNS. } & \multicolumn{4}{|c|}{ UNS. } \\
\hline \multicolumn{2}{|c|}{$\begin{array}{l}\text { Total and mean: } \\
\text { Pole position: }\end{array}$} & $6(16)$ & 324 & 09 & 33 & $\begin{array}{l}268 \\
205^{\circ} \mathrm{E}\end{array}$ & $\begin{array}{l}06 \\
02^{\circ} \mathrm{N}\end{array}$ & 23 \\
\hline \multicolumn{9}{|c|}{ Basalts } \\
\hline $4 \mathrm{PM}$ & 22 & 3 & 281 & -18 & 21 & 282 & 14 & 22 \\
\hline PM & $24^{2)}$ & 2 & 320 & -57 & 26 & 060 & -25 & 31 \\
\hline \multicolumn{2}{|c|}{$\begin{array}{l}\text { Total and mean: } \\
\text { Pole position: }\end{array}$} & $2(5)$ & 298 & -37 & 28 & $\begin{array}{l}261 \\
207^{\circ} \mathrm{E}\end{array}$ & $\begin{array}{l}20 \\
08^{\circ} \mathrm{N}\end{array}$ & 26 \\
\hline \multicolumn{9}{|c|}{ Metasediments } \\
\hline $6 \mathrm{M}$ & 210 & 2 & 048 & -81 & 27 & 247 & -31 & 24 \\
\hline M & 223 & 3 & \multicolumn{2}{|c|}{ UNS. } & \multicolumn{4}{|c|}{ UNS. } \\
\hline D & 110 & 3 & 222 & -33 & 10 & 340 & -44 & 09 \\
\hline \multicolumn{2}{|c|}{$\begin{array}{l}\text { Total and mean: } \\
\text { Pole position: }\end{array}$} & $2(5)$ & 315 & -55 & 30 & $\begin{array}{l}292 \\
181^{\circ} \mathrm{E}\end{array}$ & $\begin{array}{l}-36 \\
01^{\circ} \mathrm{S}\end{array}$ & 21 \\
\hline
\end{tabular}

The corrections applied for tilt do not refer to the regional $\mathrm{N} 35^{\circ}-45^{\circ} \mathrm{W}$ attitude with subvertical dips but to the locally recorded attitudes.

1) UNS.: magnetically unstable. 2) Reversed polarity: the serpentinites are unstable. 
in spite of the fact that one can argue that this criteria is worthless when some of the tilting (but not all!) is about $90^{\circ}$. As the time interval between the Hudsonian orogeny and the intrusive and extrusive events is short ( $\leq 100 \mathrm{~m} . \mathrm{y}$. ), the largest fraction of the NRM component is then of thermal origin.

\section{Interpretation of Paleopole, Late Aphebian Paleolatitude and Climate}

The pole position of the intrusive and extrusive formations investigated falls in the North Pacific ocean or its antipode if the poles are reversed. The inclination of these rock formations is low indicating that they were intruded in low latitude. During late Aphebian time (the younger (uppermost) division of the Lower Proterozoic Era), the central Labrador Trough was situated well within the tropics. Gypsum only forms today in arid zones in the vicinity of the equatorial circle. The assumption is made that fossil gypsum bore the same relation to the ancient equator. Gypsum was found in the sedimentary sequences interlayered with the extrusive rocks of the region (Dr. E. Dimroth, personal communication).

\section{Discussion of the Results}

The initial directions of magnetization are scattered, but the scattering is reduced by magnetic cleaning in a peak field of $250 \mathrm{Oe}$. The scattering is attributed to temporary components acquired in the laboratory, viscous components acquired in the Earth's magnetic field, a fraction of chemical magnetization, secular variation during the initial cooling and measuring errors. A very high proportion of the opaque minerals are small to medium sized magnetite crystals which are considered to dominate the magnetic properties of the rocks. Minute quantities of hemo-ilmenite are occasionally present. Many sites (6 or 7) yielded mixed polarities but the preponderance of normal polarities is significant, the reversed magnetization is thought to reflect a reversed ambient field at the time of intrusion. The paleolatitude at the time of intrusion of these rocks was close to the equator suggesting a warm climate in late Aphebian time. The paleopole obtained does not compare with the sequence of apparent polar wandering for the interval 2,100 to 1,300 m.y. established by McGlynn et al. (1974). However, this paleopole position is relatively close to the one of Michael gabbro (age $\simeq 1,500$ m.y.) obtained by FAHRIG and LARochelle (1972).

The writer wishes to acknowledge the incommensurate help of Mr. Jean L. Roy and Dr. E. Irving, Earth Physics Branch and Dr. John Foster of the Geological Survey of Canada, all three of the Department of Energy, Mines and Resources, Ottawa, for the installation of the paleomagnetic laboratory of the University of Laval, and to thank them for their invaluable discus- 
sions and advice on this work. Mr. Maurice A. Côté made the measurements. The research described in this paper has been supported by the National Research Council of Canada Grant No. A7070-110 (1972-73) and by the Geological Survey of Canada (Grant No. EMR-2300-1, 1974-75). Dr. Erich Dimroth of the Department of Natural Resources of the Province of Quebec and his geological survey mapping group collected the oriented samples.

\section{REFERENCES}

Baragar, W.R.A., Ahr Lake map-area, New Quebec, Geol. Surv. Can., Pap., 57-7, 6, 1958.

Baragar, W.R.A., Petrology of basaltic rocks in part of the Labrador Trough, Bull. Geol. Soc. Am., 71, 1589-1644, 1960.

Baragar, W.R.A., Wakuach Lake, Quebec-Newfoundland, Geol. Surv. Can., Pap., 62-38, 4, 1963.

Baragar, W.R.A., Wakuach Lake map-area, Geol. Surv., Can., Mem., 344, 174, 1967.

Dimroth, E., Romanet Lake area, New Quebec, Que. Dep. Nat. Resour., Prelim. Rep., No. 523, $13,1965 \mathrm{a}$.

Dimroth, E., Otelnuk Lake area, New Quebec, Que. Dep. Nat. Resour., Prelim. Rep., No. 532, 22, 1965 b.

Dimroth, E., Dunphy Lake area, New Quebec, Que. Dep. Nat. Resour., Prelim. Rep., No. 557, $16,1967$.

Dimroth, E., Castignon Lake area, New Quebec, Que. Dep. Nat. Resour., Prelim. Rep., No. 571, 54, 1969.

Dimroth, E., The evolution of the Labrador geosyncline, Bull. Geol. Soc. Am., 81, 2717-2742, 1970.

Diмroth, E., The evolution of the central segment of the Labrador geosyncline. II. The ophiolitic suite, N. Jahrb. f. Geol. u. Pal. Abh., 137, 209-248, 1971.

Dimroth, E., W.R.A. BARAgAR, R. Bergeron, and G.D. JACKson, The filling of the circumUngava geosyncline. Symposium on basins and geosynclines of the Canadian shield, Geol. Surv. Can., Pap., 70-40, 45-142, 1970.

Donaldson, J.A., Marion Lake map-area, Quebec-Newfoundland, Geol. Surv. Can., Map, 17$1959,1959$.

Donaldson, J.A., Marion Lake map-area, Quebec-Newfoundland, Geol. Surv. Can., Mem., 338, 85,1966 ,

FAHRIG, W.F. and D.L. Jones, Palaeomagnetic evidence for the extent of Mackenzie igneous events. Can. J. Earth Sci., 2, 278-298, 1969.

Fahrig, W.F. and A. Larochelle, Paleomagnetism of the Michael gabbro and possible evidence of the rotation of Makkowik Subprovince, Can. J. Earth Sci., 9(10), 1287-1296, 1972.

Fisher, R.A., Dispersion on a sphere, Proc. R. Soc. London, Ser. A, 217, 295-305, 1953.

Frarey, M.J., Willbob Lake, Quebec and Newfoundland, Geol. Surv. Can., Pap., 52-16, 4, 1952.

Frarey, M.J., Menihek Lakes (east half), Quebec and Newfoundland, Geol. Surv. Can., Map, 1087A, 1961.

Frarey, M.J., Willbob and Thompson Lake map-areas, Quebec and New foundland, Geol. Surv. Can., Mem., 348, 73, 1967.

FRYER, B.J., Age determinations in the Circum-Ungava geosyncline and the evolution of Precambrian banded iron formations, Can. J. Earth Sci., 9(6), 652-664, 1972.

Irving, E., Paleomagnetism and Its Application to Geological and Geophysical Problems, pp. 399, John Wiley \& Sons, New York, 1964.

Irving, E., J.K. PARK, and J.C. McGlynn, Paleomagnetism of the Et-Then group and Makenzie diabase in the Great Slave Lake area, Can. J. Earth Sci., 9, 744-755, 1972. 
McGlynn, J.C., G.N. Hanson, E. Irving, and J.K. Park, Paleomagnetism and age of Nonacho group sandstones and associated sparrow dikes, district of Mackenzie, Can. J. Earth Sci., 11(1), 30-42, 1974.

MCGLYNN, J.C. and E. IRving, Paleomagnetism of early Aphebian diabase dyke from the Slave structural province, Canada, Tectonophysics, 26, 23-38, 1975.

SEGUIN, M.K., Etude et application du magnétisme rémanent naturel à la découverte de gisement de taconite magnétique, Pure Appl. Geophys., 97(5), 156-174, 1972a.

SEGUIN, M.K., The magnetic properties of the diabase dikes of the central part of the Labrador trough, Naturaliste Canadien, 99, 635-655, $1972 \mathrm{~b}$.

SEGUIN, M.K., Paleomagnetism of diabase dikes of the West Central sector of the Labrador Trough, Abstract, Geol. Assoc. Can. Ann. Meeting, 83, 1974.

Symons, D.T.A. and M. Stupavskx, A rational paleomagnetic stability index, J. Geophys. Res., 79, 1718-1720, 1973. 